\title{
Wifliam Rainep 峝arper.
}

\author{
By Professor Ira Maurice Price, Ph.D., B.D., University ol Chicago.
}

William Rainey Harper, Ph.D., D.D., LL.D., was best known to the world as the President of the University of Chicago. His phenomenal career for the last thirty years displays some of the remarkable elements of character that made possible the results achieved.

He was born of Scotch-Irish descent, 26th July I 856 , at New Concord, Ohio, the location of Muskingum College, an institution under control of the United Presbyterian body. At the age of fourteen he graduated, and pronounced the Hebrew oration. At nineteen he completed a graduate course at Yale University, winning the degree of $\mathrm{Ph} . \mathrm{D}$. In this same year he married, and began teaching in the South. The next year he was made instructor and Principal of the Preparatory Department of Denison University, Granville, Ohio. At this place he was converted and baptized into the membership of the Baptist Church. In 1879 he was appointed to the Chair of Hebrew and Cognate Languages in the Baptist Union Theological Seminary, Morgan Park, Illinois. In I 886 he was chosen Professor of Semitic Languages at Yale University, and in ISS9, of Biblical Literature at the same institution, holding these two chairs at one and the same time. In 189 I he accepted the Presidency of the newly projected University of Chicago. After nearly one year's suffering from intestinal cancer, he passed away, I oth January I 906.

Dr. Harper's chosen profession was teaching. And it was his success in this line that gave him his reputation and power in all his varied activities. His career as a Hebrew teacher and scholar began with his occupancy of the Chair in the Theological Seminary at Morgan Park. There he began the preparation of, and completed, Hebrew text-books on the inductive plan, which have already reached their twentieth edition and are largely used in American institutions. He also inaugurated the teaching of Hebrew by correspondence, which from that day to this has been in successful operation, and has enrolled thousands of students. In I 880 he began to teach Hebrew in the summer vacation; and this plan grew into a series of Hebrew Summer Schools held in different parts of the country and enrolling hundreds of students. In I 882 he established The Hebreae Student-later changed to The Old Testament Student, to The Old and Nerv Testament Student, to the now Biblical Forld. In I $\mathrm{SS}_{4}$ the first number of the Hebraica appeared, later changed to The American Journal of Scmitic Languages and Literatures. In this same period he became Principal of the Chautauqua School of Liberal Arts, a far-reaching educational scheme, with headquarters at Chautauqua, New York. In short, Dr. Harper revolutionized the interest in the study of Hebrew in this country. He constructed practical text-books that were usable according to the best modern principles of pedagogy.

On the popular side, he became a master of the public exposition of the Scriptures. He made the Minor Prophets teem with interest, and the Psalms speak forth their joys and their peaceful composure in the presence of the Lord of mankind. To popularize the study of the English Bible he originated 'the American Institute of Sacred Literature,' an organization designed to teach the Bible by correspondence and establish reading courses thereon.

The teacher was the originator and deviser of all these plans of distributing knowledge, and of stirring up widespread interest in the Bible. Dr. Harper's twenty-five years of active service in teaching, showed him to be a master rarely equalled. He was enthusiastic, contagiously so, was thorough, open-minded, severely exacting, reverent, sympathetic, genial, and always optimistic and buoyant in spirits. These qualities were so combined as to make him a most attractive personality, a natural leader among men.

As a scholar, Dr. Harper's ability has shown itself to the best advantage in his volume on Amos and Hosea in the "International Critical Commentary' Series, and his two small brochures on the Hebrew text of these two prophets.

But the monumental work of Dr. Harper, and that for which he will be chiefly remembered, will be the organization and development of the University of Chicago. Though pre-eminently a teacher, and by instinct a scholar, he was an administrator and executive of phenomenal parts. Not hampered by any traditions, he was free to 
originate, combine, expand, or modify existing schemes of education, and thus to establish an institution sui seneris. With prophetic foresight and scholarly discrimination, he selected for his first group of professors, in several large departments, men of known ability and world renown. Such a nucleus drew students from the ends of the earth. Mr. John D. Rockefeller of New York, as well as a noble body of Trustees, stood close to the President, and supported his broad and expansive plans, and gave the University a standing almost from the very first. Dr. Harper's position at its head gave him a prominent place in the educational councils of the country.

As teacher, scholar, administrator, or man, Dr. Harper was of those who occupied the chief seat in American educational annals of the last twentyfive years.

\title{
Ebe Ereagure Eommitted to your Ebarge.
}

\author{
By the Rev. A. E. Burn, D.D., Rector of Handsworth, Birmingham.
}

\begin{abstract}
' Ye are holy unto the Lord; the vessels are holy also; and the silver and gold are a freewill offering unto the Lord God of your fathers. Watch ye, and keep them, until ye weigh them before the chief of the priests and the Levites, and chief of the fathers of Israel, at Jerusalem, in the chambers of the house of the Lord.' -Ezra viii. 28, 29.
\end{abstract}

THE weary years of captivity are ended. The party of exiles whom Ezra is about to lead back from Babylon to the land of their fathers is ready for the toilsome march across the desert. The king, Artaxerxes, is well disposed. He has restored the holy vessels which had been taken from the Temple more than a century before. He and his nobles have given princely gifts of money for the treasury of God. Shall they ask him for a guard to protect them against the marauders of the desert, the wandering Bedawin, at all times quick to hear of so wealthy a caravan, to swoop, and conquer, and vanish, leaving but a few dead men, whose bones shall soon bleach by the wayside forgotten like so many more.

A sad end this to their high hopes. But there is another point of view. To ask for a guard would be to show lack of faith in the God of their fathers. They are about to engage in what is uniquely God's work, to carry back the holy vessels to the restored Temple, and to give a new stimulus to the direction of the national life of the people which shall have, please God, an influence on the lives of generations yet unborn. Let them trust God to protect His ministers.

In Ezra's own words: 'I proclaimed a fast

${ }^{1}$ A Sermon preached at the September Ordination in Birmingham Cathedral. there, at the river of Ahava, that we might aftlict ourselves before our God, to seek of him a right way for us, and for our little ones, and for all our substance. For I was ashamed to require of the king a band of soldiers and horsemen to help us against the enemy in the way: because we had spoken unto the king, saying, The hand of our God is upon all them for good that seek him; but his power and his wrath is against all them that forsake him. So we fasted and besought our God for this: and he was intreated of us.' Do you say: 'A quixotic resolve'? 'More things are wrought by prayer than this world dreams of.' The final preparations are made. A picked body of twelve priests and twelve Levites receive the chargel of the holy vessels and the treasure in the words which I have chosen for my text. They make the venture of faith.

We will not follow them in imagination on the march, nor to their joyful arrival in Jerusalem. All subsequent Jewish history was in part moulded by their influence in answer to the prayers of Ezra and his little company. Great issues were at stake on that day of decision. But we must not stay to enumerate them. I wish to make of this graphic picture of the halt by the waters of the Ahava, of the dedication of these ministers of the sanctuary, a starting-point for our meditation on the solemn 